\title{
Evolutionary and taxonomic relationships of Acacia s.l. (Leguminosae: Mimosoideae)
}

\author{
Joseph T. Miller ${ }^{\mathrm{A}, \mathrm{C}}$ and David Seigler ${ }^{\mathrm{B}}$ \\ ${ }^{A}$ Centre for Australian National Biodiversity Research, CSIRO Plant Industry, The Australian National Herbarium, \\ GPO Box 1600, Canberra, ACT 2601, Australia. \\ ${ }^{B}$ Department of Plant Biology, University of Illinois, Urbana, IL 61801, USA. \\ ${ }^{\mathrm{C} C}$ Corresponding author. Email: joe.miller@csiro.au
}

\begin{abstract}
The species of Acacia s.l. are currently undergoing a taxonomic upheaval. This is due, in large part, to recent molecular work that has confirmed previous morphological studies and concluded that the genus is not monophyletic. At least five monophyletic lineages have been defined within the genus and, largely on the basis of molecular data, these are distributed throughout the tribes Acacieae, Ingeae and Mimoseae of the Mimosoideae. We provide new and review previous molecular data used to redefine the generic classification of the genus into five segregate genera. The present study doubles the number of plastid base pairs compared with previous studies, to over $7 \mathrm{~kb}$ of aligned sequence. These data confirm previous clades and the present is the first to identify robust support for relationships among clades on the backbone of the phylogeny. The support for Vachellia is stronger than for any subclade within it. However, the support for Senegalia s.s. is weaker than it is for each of two subclades within it. There is no support for the former tribal classification with the enlarged dataset. The nomenclatural implications of which clades are recognised at a generic level are discussed.
\end{abstract}

Additional keywords: molecular phylogeny, systematics.

Received 9 December 2011, accepted 3 May 2012, published online 6 June 2012

\section{Introduction}

Although several species of Acacia s.l. were first described by Linnaeus (1753) under the broadly defined genus Mimosa L., the genus Acacia Mill., comprising 24 diverse species, mainly from the Americas, but with the pre-Linnaean 'ACACIA vera. J. $B$ ' said to be 'The true Egyptian Acacia', was published by Miller (1754). As Miller had not by then adopted Linnaean binary nomenclature, none of his species was provided with a binomial. Subsequently, Miller (1757) identified his ACACIA vera. $J$. $B$ species with a species that Linnaeus (1753) had named Mimosa scorpioides, later selected as the type of Acacia (Abrams 1944). Numerous new species were subsequently described, notably by Willdenow (1806), but the genus Acacia remained at best a loosely coherent group. Beginning in the 1830s and culminating in 1875, George Bentham (Bentham 1842, 1875) revised Acacia, narrowing the limits of the genus and transferring numerous species to other genera. Ultimately, he recognised six series in a widespread, pantropical-subtropical genus Acacia s.l., with centres of diversity in the Americas, Africa and Australia (Bentham 1842). Few other changes appeared, until, in 1928, Britton and Rose (Britton and Rose 1928) subdivided the genus Acacia into several new genera, largely on the basis of fruit characters. However, most of these genera were not accepted by later systematists, and Bentham's 1875 (Bentham 1875) treatment remained the basis for classification until late in the
20 th century. At that time, $\sim 1450$ species had been ascribed to the genus, making it one of the largest of all plant genera (Maslin et al. 2003; Lewis et al. 2005). As more information accumulated, Vassal (1972) segregated Acacia s.l. into three subgenera. The distribution of the largest of these, Acacia subg. Phyllodineae (DC.) Ser., with $~ 960$ described species, was centred in Australia (Maslin et al. 2003), with a smaller number in Madagascar, Asia and various Pacific Islands. The other two subgenera, Acacia subg. Acacia and Acacia subg. Aculeiferum Vassal (Lewis et al. 2005), shared a similar distributional pattern in Africa and the Americas, with fewer species in Asia, Australia and the Pacific region (Table 1).

Later, Pedley (1989) proposed recognition of these subgenera as genera Racosperma (DC.) Mart., Acacia s.s., and Senegalia Raf. respectively. Although it was by then well established that Acacia s.l. comprised several divergent groups, the relationship of these groups to each other and to members of tribes Ingeae and Mimoseae remained uncertain, owing to a lack of a robust and well sampled phylogeny. Maslin $(1987,1989)$ urged caution before implementation of such major taxonomic changes with insufficient supporting data (see Pedley's responses: Pedley 1987, 1989).

The taxonomy of Acacia became more contentious in 2005, when a proposal (Orchard and Maslin 2003) to retypify the generic name Acacia s.l. from A. scorpioides L., a synonym 
Table 1. Current status of generic names applied to higher-level monophyletic units of Acacia s.l. New combinations have been published for the American and Australian species, whereas only a few new combinations have been proposed for the African and Asian species (Banfi and Galasso 2008; Mabberley 2008; Seigler and Ebinger 2010). No species have naturally occurring ranges in both Africa and the Americas

\begin{tabular}{llll}
\hline Pedley 1978 & Pedley 1986 & Generalised distribution & Genus, post retypification (2005) \\
\hline Acacia subg. Phyllodineae & Racosperma & Australia, Pacific region & Acacia s.s. (type A. penninervis) \\
Acacia subg. Acacia (type A. nilotica) & Acacia & Americas, Africa, Asia & Vachellia \\
Acacia subg. Aculeiferum & Senegalia sect. Senegalia & Americas, Africa, Asia & Senegalia \\
Acacia subg. Aculeiferum. sect. Filicineae & Senegalia sect. Filicinae & Americas & Acaciella \\
Acacia subg. Aculeiferum 'coulteri group' & Senegalia sect. Senegalia & Americas & Mariosousa \\
Acacia subg. Aculeiferum 'skleroxyla' group & Senegalia sect. Senegalia & Americas & Not presently recognised \\
\hline
\end{tabular}

of A. nilotica, an African species, to an Australian species, A. penninervis, was approved at the XVII International Botanical Congress at Vienna (McNeill et al. 2005). Acceptance of this retypification remains controversial (Luckow et al. 2005; van Rijckevorsel 2006; Moore 2007, 2008; Smith et al. 2010, 2006; Brummitt 2011; Linder and Crisp 2011; Moore and Cotterill 2011; Moore et al. 2011a, 2011b; Smith and Figueiredo 2011; Thiele et al. 2011). However, the retypification was upheld recently at the XVIII International Botanical Congress in Melbourne in July 2011 (McNeill and Turland 2011; Smith and Figueiredo 2011).

Early molecular phylogenetic data generated to resolve these questions (Clarke et al. 2000; Robinson and Harris 2000) consisted largely of chloroplast restriction fragment length polymorphism data for a limited sample of either American or African taxa. Although these studies largely supported previous subgeneric and generic groupings, interpretations were limited by inadequate geographic and taxon sampling. Subsequent studies of chloroplast and nuclear DNA in which critical taxa of tribes Ingeae and Mimoseae, as well as taxa from Acacia s.l., have been sampled more broadly (Miller and Bayer 2000; Miller and Bayer 2001; Luckow et al. 2003; Miller et al. 2003; Bouchenak-Khelladi et al. 2010; Brown et al. 2011), established that (1) Acacia s.l. is non-monophyletic, (2) two of the three major groups within Acacia s.l. are monophyletic and the third is non-monophyletic, (3) some Acacia s.l. species are more closely related to species of tribe Mimoseae than to other Acacia s.l. lineages and (4) the predominantly Australian clade is more closely related to species of tribe Ingeae than to other Acacia s.l. lineages. On the basis of both morphological and molecular data, it is widely accepted that the non-monophyletic genus Acacia s.l. should be subdivided.

Taxonomic changes to reflect this non-monophyly have proceeded apace over the past 5 years. Most American (Seigler et al. 2006b; de Queiroz 2008; Seigler and Ebinger 2009) and a smaller number of African and Asian species (Banfi and Galasso 2008; Mabberley 2008; Seigler and Ebinger 2010) of Acacia subg. Aculeiferum Vassal have been transferred to the genus Senegalia. A smaller number of species has been moved to the American genera Mariosousa (Seigler et al. 2006a) and Acaciella (Rico Arce and Bachman 2006).

In a similar manner, but considering the retypification of Acacia (Seigler and Ebinger 2005), most American (Seigler and Ebinger 2005) and Australian (Kodela and Wilson 2007) species of Vassal's former Acacia subg. Acacia have been transferred to the genus Vachellia. New combinations in
Vachellia have been published for a smaller number of African and Asian species (Banfi and Galasso 2008; Mabberley 2008; Seigler and Ebinger 2010).

Current phylogenies provide robust support for the recognition of Senegalia, Mariosousa, Acaciella, Vachellia and Acacia s.s. However, our knowledge of the species relationships and infrageneric groups within these genera is not well established. Furthermore, only modest amounts of molecular data relevant to resolving relationships of these genera to tribes Ingeae and Mimoseae are available. Increased sampling of critical species and geographic regions will probably lead to recognition of additional segregates. Because former tribal relationships within subfamily Mimosoideae are now in disarray, new phylogenetic data will be vital for establishing an acceptable tribal and generic system of classification.

Previous molecular studies agree on the monophyly of major clades such as Vachellia, Senegalia s.s., Mariosousa, Acaciella and Acacia s.s. Although previous plastid studies have shown similar backbone topologies, none have demonstrated bootstrap support greater than $90 \%$ for phylogenetic relationships among these clades. The present study aimed to recover, with robust support, these relationships by analysing a dataset comprising double the number of plastid base pairs of that in previous work: six plastid loci and $7 \mathrm{~kb}$ of aligned sequence. A second aim was to investigate relationships within Senegalia s.s. and Vachellia. For both aims, exemplars were used to represent well supported clades.

\section{Materials and methods}

Species were selected to sample at least eight species each of Senegalia and Vachellia and at least three species of each lineage of Acacia s.l. (Appendix 1). Ingroup taxa were selected from those available on the basis of previous results (Luckow et al. 2003; Miller et al. 2003; Brown et al. 2008). These included species of Mimosa, Anadenanthera Speg. and Piptadenia Benth. of tribe Mimoseae. Seventeen samples of 10 Ingeae genera were included along with two samples of the monotypic genus Faidherbia A.Chev., being the only other genus previously included in tribe Acacieae. Outgroups were selected on the basis of the results of Luckow et al. (2003) and included species of Desmanthus Willd., Leucaena Benth., Neptunia Lour. and Prosopis L., also of tribe Mimoseae.

Material used in the present study was collected in the field and stored in silica gel or grown from seeds from various seed banks. When seeds were used, they were germinated and young leaves 
harvested. DNA was extracted using a Qiagen DNeasy Plant Mini Kit (Qiagen Inc., Valencia, CA).

Sequences of the following six plastid loci were obtained: (1) $m a t \mathrm{~K}$ gene and flanking $\operatorname{trnK}$ introns; (2) $p s b \mathrm{~A}-t r n \mathrm{H}$ intergenic spacer; (3) $\operatorname{trn} \mathrm{L}$ intron; (4) $\operatorname{trn} \mathrm{L}-\operatorname{trn} \mathrm{F}$ intergenic spacer region; (5) $n d h \mathrm{~F}$ and (6) $a t p \mathrm{~B}-r b c \mathrm{~L}$ intergenic spacer. The matK gene and flanking $t r n \mathrm{~K}$ introns, the $p s b \mathrm{~A}-t r n \mathrm{H}$ intergenic spacer and $\operatorname{trn} \mathrm{L}-\operatorname{trn} \mathrm{F}$, intron and intergenic spacer regions were sequenced following methods outlined in Miller and Bayer (2001). For 31 sampled specimens, these three regions were previously sequenced. Thirty specimens were originally sequenced for the study. The $n d h \mathrm{~F}$ region was amplified and sequenced using the 1318F and 2110R (Olmstead and Sweere 1994) primers. The $a t p \mathrm{~B}-r b c \mathrm{~L}$ intergenic spacer was amplified and sequenced using the $a t p \mathrm{~B}-\mathrm{F}$ and $a t p \mathrm{~B}-$ spacer $\mathrm{R}$ primers of Manen et al. (1994). All $n d h \mathrm{~F}$ and $a t p \mathrm{~B}-r b c \mathrm{~L}$ intergenic spacer sequences were newly generated for the study.

Data were generated by using the purified DNA as a template for direct sequencing, using the one-eighth reactions of the BIG Dye v 3.1 Terminator Cycle Sequencing Ready Reaction Kits (Applied Biosystems, Carlsbad, CA) electrophoresed on a 3730-capillary sequencer.

Chromatographic traces and contiguous alignments were edited using Sequencher(Gene Codes Corporation, Ann Arbor, MI, USA). Sequences were aligned manually with minimal gaps and base substitutions. Uncertain base positions, generally located close to the priming sites, and regions of uncertain alignment were excluded from the phylogenetic analysis. Informative insertion-deletion events (indels) were identified and coded as binary characters and gaps were treated as missing data.

\section{Data analysis}

Bayesian analysis was performed using MrBayes version 3.1.2. (Ronquist and Huelsenbeck 2003). Sequence data were divided into six partitions, one for each locus. A separate GTR $+\mathrm{I}+$ gamma model was applied to each of these partitions. Indel characters were included as a separate partition and a standard discrete state model with a gamma-shape parameter was applied to this partition. A Markov chain Monte Carlo search was run for 50 million generations, with trees sampled every 50000 generations. MrBayes performed two simultaneous analyses starting from different random trees $($ Nruns $=2)$, each with four Markov chains (Nchains $=6$ ). A total of $25 \%$ of the trees were discarded and the run ended with an average standard deviation of split frequencies of $<0.004$

Maximum parsimony analyses were performed with the heuristic search option (excluding uninformative characters) in PAUP* 4.02 (Swofford 2003). A four-step search method for multiple islands was performed with 10000 random replicates (Olmstead and Sweere 1994). Support for internal branches was evaluated by the heuristic bootstrap method, with 10000 bootstrap replicates each with 10 random sequence-addition replicates with TBR (Felsenstein 1985).

\section{Results}

As expected, the results of the present study support previous studies concerning the non-monophyly of Acacia s.l. (Fig. 1).
Clades A (Vachellia) and F (Acacia s.s.) are each monophyletic and have strong support (1.0 Bayesian posterior probability and $>90 \%$ bootstrap support).

On the basis of analysis with the four outgroup taxa suggested by a previous study (Luckow et al. 2003), the Vachellia clade (Clade A) is nested within a paraphyletic tribe Mimoseae. It comprises two subclades, one containing African species and the other American species (Fig. 2A). Although the number of species included in the present analysis is small, these geographically based clades are strongly supported. The type of the generic name, $V$. farnesiana, applies to a species belonging to the American clade (Miller and Bayer 2003). The branch leading to the Vachellia clade (Fig. $2 A$ ) is longer than any branch within the clade, suggesting that a large number of characters are shared by all species of Vachellia. The two subclades are less strongly supported than the clade as a whole.

The node that contains Clades B-F and the Ingeae (Fig. 1, marked by \#) is well supported (Bayesian posterior probability of 1.0 and bootstrap value of $97 \%$ ). Previous plastid datasets reported lower bootstrap values for this node $(71 \%$, BouchenakKhelladi et al. 2010; 82\%, Miller et al. 2003; and 83\% Luckow et al. 2003). Brown et al. (2008) reported $80 \%$ bootstrap support with nuclear rDNA sequence; however, they did not sample Mimoseae taxa.

The clade representing the core of the genus Senegalia (Clade B), denoted with an asterisk in Fig. $2 B$, is moderately supported (Bayesian posterior probability of $1.0,72 \%$ bootstrap value) and consists of two sister clades (each with Bayesian posterior probability of 1 and bootstrap value of $100 \%$ ). One clade (B1, Fig. 2B) consists of African-Asian species (Acacia subgenus Aculeiferum sect. Aculeiferum) (Vassal 1972). The second clade (B2, Fig. 2B) comprises species with a pantropical distribution (Acacia subgenus Aculeiferum sect. Monacanthea) (Vassal 1972). The longest branches and most strongly supported groups are these two subclades (B1 and B2) rather than the larger clade of B1 + B2 (i.e. the genus Senegalia, apart from species related to $S$. skleroxyla). Phylogenetic relationships within Clade B are poorly understood; this group is in particular need of further study.

Each of Clades B-E represents a segregate group of Acacia subg. Aculeiferum. These clades collectively form a paraphyletic grade (Fig. 1, marked by \#) with respect to the Ingeae and the Australian acacias (Clade F). Two of these, Clades D and E, correspond directly to the previously described genera Acaciella (16 species) and Mariosousa (13 species), both of which have centres of diversity in Mexico. Clade C consists of a group of species related to $S$. skleroxyla. In the present analysis, two species (S. vogeliana and S. visco) are supported as members of this clade, with only low Bayesian posterior probabilities (0.82 and 0.67 ; Fig. 2). This presently undescribed group may contain as many as 10 mostly poorly known species and requires additional study; most of the probable species are currently recognised in Senegalia. Clade D (Mariosousa) caps a short branch with moderately strong support. The segregate genus Acaciella and its sister clade Calliandra each have many unique indels (Clade E, Fig. 2A).

These plastid data support three nodes in the Ingeae: Acacia s.s. that have bootstrap values above $90 \%$. None of the previous plastid studies has shown bootstrap support above 


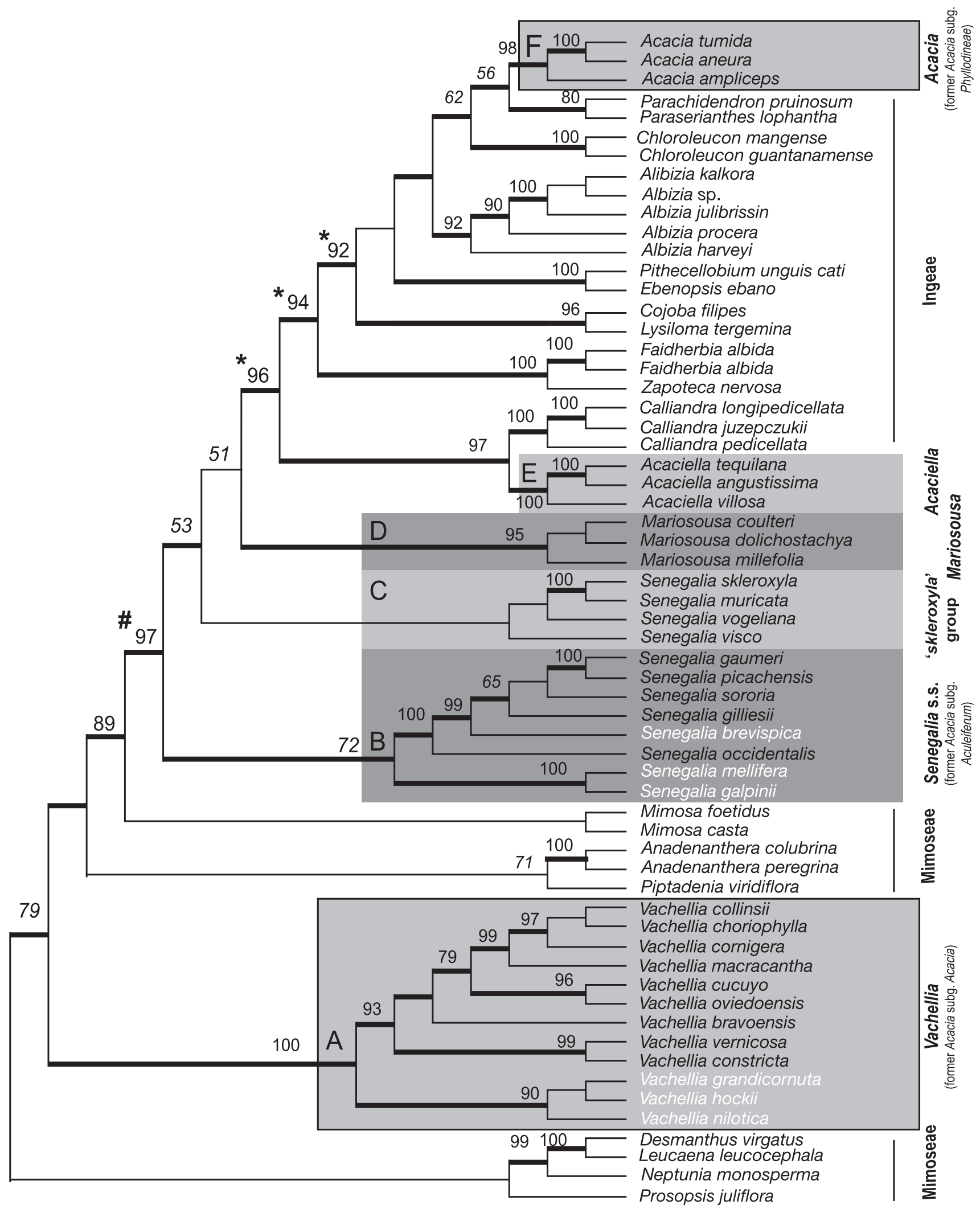

Fig. 1. Topologies of the Bayesian trees without branch lengths. The three boxes indicate the three subgenera of Acacia s.l. Shaded groupings indicate segregate and suggested segregate groupings. Bold lines indicate Bayesian posterior probability above $95 \%$. African Vachellia and Senegalia are indicated in white text. Bootstrap values are given above nodes and bootstrap values below $80 \%$ are in italic. 


\section{A}
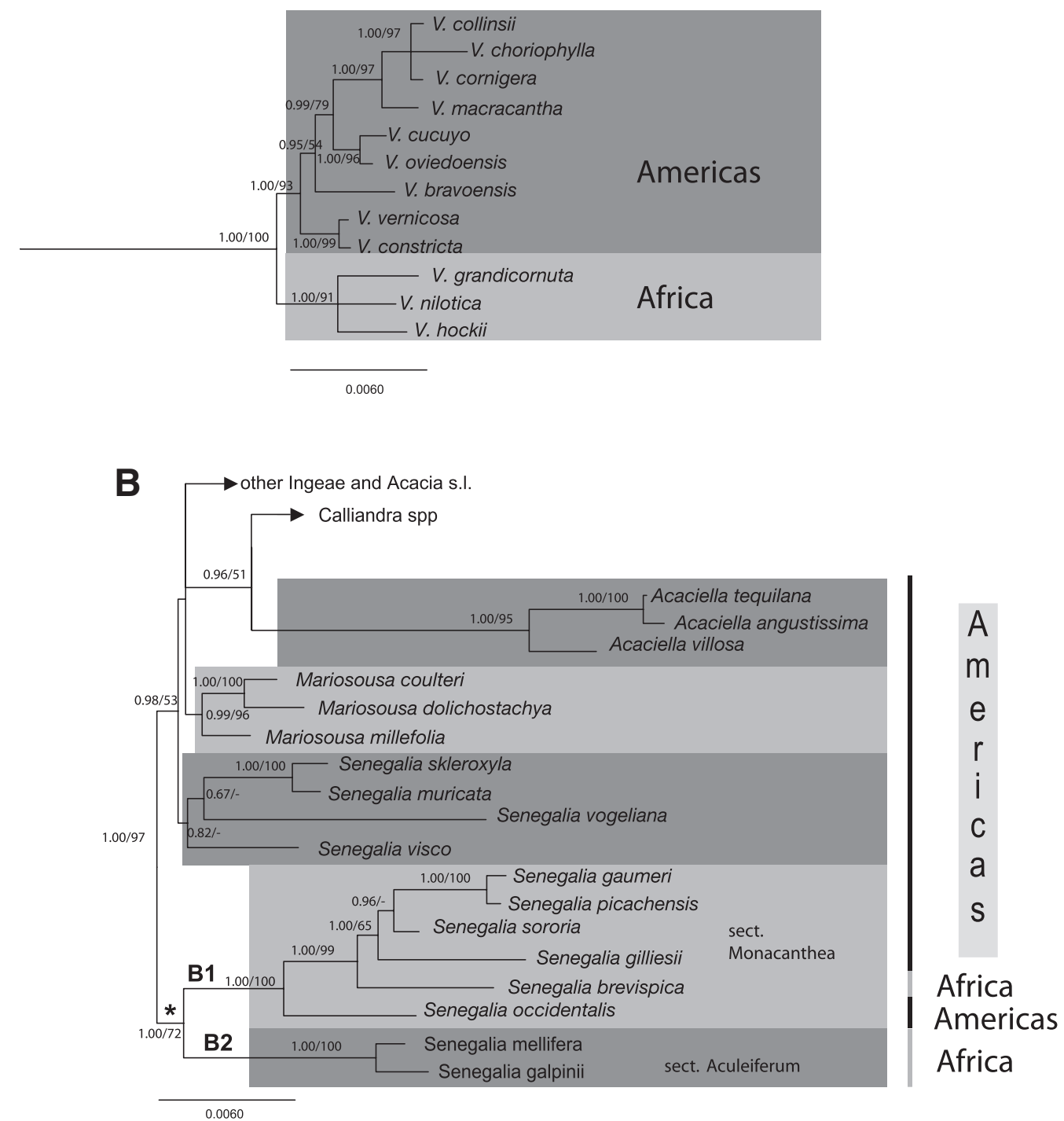

Fig. 2. Topologies of the Bayesian trees with branch lengths. Posterior probability and bootstrap support values are given.

A. Vachellia and B. Senegalia s.l.

$80 \%$ for node supporting two genera within the Ingeae. Brown et al. (2008) used nuclear-DNA sequences and detailed sampling of the Ingeae genera to provide high bootstrap support (97\%) for the Ingeae : Acacia s.s. node. The Ingeae has been sampled more intensively in a recent study (Brown et al. 2008); there, Calliandra was not related to the single Acaciella species sampled. These findings suggest that the apparent Calliandra-Acaciella sister-group relationship in the present study could be an artefact caused by long-branch attraction.

\section{Discussion}

Despite considerable evidence to the contrary (see above), one proposed taxonomic solution of the Acacia dilemma is to maintain Acacia s.l. as a single entity (Smith and Figueiredo 2011). However, it should be noted that under this concept, the only acceptable interpretation of phylogenetic studies based on molecular data is to maintain most of subfamily Mimosoideae in a single genus, Mimosa, with more than 4000 species; the results of both morphological and molecular phylogenetic analyses suggest better alternatives. Vachellia species (Clade A, both African and American) and Acacia s.s. species (Clade F, primarily Australian) both form strongly supported clades and should be maintained as distinct genera. As noted above, the genera Acaciella and Mariosousa (Clades D and E) have previously been segregated from within Acacia subg. Aculeiferum and also form robustly supported monophyletic groups. Pending additional morphological and molecular study and expanded sampling, the group of species related to S. skleroxyla (Clade C) may represent yet another group worthy of segregation from Acacia subg. Aculeiferum. If the placement of $S$. visco within this clade is supported by additional data, then 
these taxa must be placed into the genus Manganaroa Speg. (Spegazzini 1921).

Clade A (Vachellia) contains two distinct groups of species, namely, one American and the other from Africa and Asia. There is stronger support for Vachellia as a whole than for either of the two subclades. The molecular phylogeny by BouchenakKhelladi et al. (2010) also found these two clades. That work, which has the best representation of African species of this clade, found two well supported subclades within the African Vachellia species. Five species, including $V$. nilotica, were sister to these main clades. There was moderate support for the African clade ( 0.78 posterior probability).

The type of Vachellia is $V$. farnesiana, applicable to an American species. Although many Asian and Australian species of this genus have not been studied in detail, both our data and those of Bouchenak-Khelladi et al. (2010) support maintenance of a single genus Vachellia. If Vachellia were to be subdivided, all Old World species would probably require a new generic name.

The remaining taxa of Acacia subg. Aculeiferum (Clade B, here referred to as Senegalia) constitute a monophyletic group. Two sections of the subgenus, Monacanthea and Aculeiferum, described by Vassal (1972) correspond to the two sister subclades of Clade A. However, the genus Senegalia remains very poorly studied. On the basis of morphological characters and a paucity of molecular data, most, if not all, American species and some African and Asian species belong to section Monacanthea, whereas many African and Asian species belong to section Aculeiferum. The type of the genus is Senegalia senegal, an African species classified by Vassal as a member of section Aculeiferum. On the basis of previous work (Miller and Bayer 2003), this species groups in a clade with other species of section Aculeiferum, here represented by S. mellifera and S. galpinii. Nonetheless, on the basis of molecular data and regardless of the Acacia type designation, Senegalia is a genus distinct from Acacia s.l. At present, the phylogeny of Senegalia is not well understood and there are insufficient data to clarify relationships within the genus. In particular, the relationships of the approximately fifty Brazilian species as well as several species in South-east Asia and northern Australia belonging to genus Senegalia have not been sufficiently studied.

The traditional tribal classification has been shown to be unnatural by DNA-sequence analyses but these have so far failed to provide sufficient support to underpin an alternative phylogenetic tribal classification. The present study, however, provides bootstrap support above $90 \%$ for several nodes on the backbone of the phylogeny. More robust sampling, with large sequence datasets, are needed, particularly in the Mimoseae and Ingeae, to further establish support for the deep nodes. These data are critical if an alternative to the tribal classification is to be developed.

Because of the iconic nature of many of these species in different countries (e.g. the ant-acacia trees of Africa and the Americas, the characteristic umbrella-topped African savannah trees, as well as the floral emblem of Australia), it is clear that changes in our understanding of the relationships and subsequent changes in names have had a direct effect on many people. Many of the common and scientific names are found in taxonomic, ecological, conservation and horticultural literature. Although acacia may well be used as a common name for various members of Acacia s.l., future use of the name Acacia s.s. should be restricted to a clade of primarily Australian plants. The data presented not only support segregation of generic groups from Acacia s.l., but point to a future necessary reorganisation of the tribal and subgeneric classification of the Mimosoideae.

\section{Acknowledgements}

J. T. Miller acknowledges NSF-Systematic Biology grant NSF-DEB 0414902. D. Seigler acknowledges support by the National Science Foundation (NSF BSR 82-15274, NSF-PCM 82-17114, NSF DEB 04-15803), University of Illinois Research Board (1994, 2001) and a Rupert Barneby Award by the New York Botanical Garden (1997). We appreciate the comments of two anonymous reviewers and Dr John S. McNeill who suggested several improvements for this publication. We also thank the curators of the many herbaria who sent specimens for this study.

\section{References}

Abrams L (1944) 'An illustrated flora of the Pacific States: Washington, Oregon, and California. Vol. 2.' (Stanford University Press: Stanford, CA)

Banfi E, Galasso G (2008) New combinations in Vachellia Wight \& Arn., formerly Acacia Mill. s.s. (Fabaceae). Atti della Società Italiana di Scienze Naturali e del Museo Civico di Storia Naturale di Milano 149, 149-150.

Bentham G (1842) Notes on Mimoseae, with a synopsis of species. London Journal of Botany 1, 319-392.

Bentham G (1875) Revision of the suborder Mimoseae. Transactions of the Linnean Society of London 30, 335-664. doi:10.1111/j.1096-3642.1875.tb00005.x

Bouchenak-Khelladi Y, Maurin O, Hurter J, van der Bank M (2010) The evolutionary history and biogeography of Mimosoideae (Leguminosae): an emphasis on African acacias. Molecular Phylogenetics and Evolution 57, 495-508. doi:10.1016/j.ympev.2010.07.019

Britton NL, Rose JN (1928) Mimosaceae. North American Flora 23, 1-194.

Brown GK, Murphy DJ, Miller JT, Ladiges PY (2008) Acacia s.s. and its relationship among tropical legumes, tribe Ingeae (Leguminosae: Mimosoideae). Systematic Botany 33, 739-751. doi:10.1600/036364408786500136

Brown GK, Murphy DJ, Ladiges PY (2011) Relationships of the AustraloMalesian genus Paraserianthes (Mimosoideae: Leguminosae) identifies the sister group of Acacia sensu stricto and two biogeographical tracks. Cladistics 27, 380-390. doi:10.1111/j.1096-0031.2011.00349.x

Brummitt RK (2011) (292) Acacia: a solution that should be acceptable to everybody. Taxon 59, 1925-1926.

Clarke HD, Downie SR, Seigler DS (2000) Implications of chloroplast DNA restriction site variation for systematics of Acacia (Fabaceae: Mimosoideae). Systematic Botany 25, 618-632. doi:10.2307/2666724

de Queiroz LP 2008. 'Leguminosas da Caatinga.' (Universidad Estadual de Feira de Santana: Feira de Santana, Brazil)

Felsenstein J (1985) Confidence limits on phylogenies: an approach using the bootstrap. Evolution 39, 783-791. doi:10.2307/2408678

Kodela PG, Wilson PG (2007) New combinations in the genus Vachellia (Fabaceae: Mimosoideae) from Australia. Telopea 11, 233-244.

Lewis GP, Schrire B, Mackinder B, Lock M (2005) 'Legumes of the World.' (Royal Botanic Gardens, Kew: London)

Linnaeus C (Ed.) (1753) 'Species Plantarum'. (Imprentis Laurentii Salvii: Stockholm)

Linder HP, Crisp M (2011) The fate of Acacia. Taxon 60, 570-571.

Luckow M, Miller JT, Murphy DJ, Livshultz T (2003) A phylogenetic analysis of the Mimosoideae (Leguminosae) based on chloroplast DNA sequence data. In 'Advances in legume systematics, part 10'. (Eds BB Klitgaard, A Bruneau) pp. 197-220. (Royal Botanic Gardens, Kew: London) 
Luckow M, Hughes C, Schrire B, Winter P, Fagg C, Fortunato R, Hurter J, Rico L, Breteler FJ, Bruneau A, Caccavari M, Craven L, Crisp M, Delgado AS, Demissew S, Doyle JJ, Grether R, Harris S, Herendeen PS, Hernández H, Hirsch M, Jobson AM, Klitgaard R, Labat BB, Lock J-N, Mac M, Kinder B, Pfeil B, Simpson BB, Smith GF, Sousa MS, Timberlake J, van der Maesen JG, Van Wyk AE, Vorster P, Willis CK, Wieringa JJ, Wojciechowski MF (2005) Acacia: the case against moving the type to Australia. Taxon 54, 513-519. doi:10.2307/25065385

Mabberley D (2008) ‘Mabberley’s Plant Book.' (Cambridge University Press: Cambridge, UK)

Manen J-F, Natali A, Ehrendorfer F (1994) Phylogeny of RubiaceaeRubieae inferred from the sequence of a cpDNA intergene region. Plant Systematics and Evolution 190, 195-211. doi:10.1007/BF00986193

Maslin BR (1987) Report of discussions at IGSM meeting no. 6 on the proposal to split Acacia. Bulletin of the International Group for the Study of Mimosoideae 15, 108-118.

Maslin BR (1989) Wattle become of Acacia? Australian Systematic Botany Society Newsletter 58, 1-13.

Maslin BR, Miller JT, Seigler DS (2003) Overview of the generic status of Acacia (Leguminosae: Mimosoideae). Australian Systematic Botany 16, 1-18. doi:10.1071/SB02008

McNeill JS, Turland NJ (2011) Major changes to the Code of Nomenclature - Melbourne, July 2011. Taxon 60, 1495-1497.

McNeill JS, Stuessy TF, Turland NJ, Hörandl E (2005) XVII International Botanical Congress: Preliminary mail vote and report of Congress action on nomenclature proposals. Taxon 54, 1057-1064.

Miller P (1754) 'The gardeners dictionary.' Abridged edn 4. (John and James Rivington: London)

Miller P (1757) ‘The gardeners dictionary.' edn 7. (John and James Rivington: London)

Miller JT, Bayer RJ (2000) Molecular phylogenetics of Acacia (Fabaceae: Mimosoideae) based on chloroplast $\operatorname{TrnK} / \mathrm{Mat} \mathrm{K}$ and nuclear histone H3-D sequences. In 'Advances in legume systematics 9'. (Eds PS Herendeen, A Bruneau) (Royal Botanic Gardens, Kew: London)

Miller JT, Bayer RJ (2001) Molecular phylogenetics of Acacia (Fabaceae: Mimosoideae) based on the chloroplast matK coding sequence and flanking trnK intron spacer regions. American Journal of Botany $\mathbf{8 8}$, 697-705. doi:10.2307/2657071

Miller JT, Bayer RJ (2003) Molecular phylogenetics of Acacia subgenera Acacia and Aculeiferum (Fabaceae: Mimosoideae), based on the chloroplast matK coding sequence and flanking trnK intron spacer regions. Australian Systematic Botany 16, 27-33. doi:10.1071/SB01035

Miller JT, Grimes JW, Murphy DJ, Bayer RJ, Ladiges PY (2003) A phylogenetic analysis of the Acacieae and Ingeae (Mimosoideae: Fabaceae) based on $\operatorname{trn\mathrm {K}}, \operatorname{mat} \mathrm{K}, p s b \mathrm{~A}-t r n \mathrm{H}$, and $\operatorname{trn} \mathrm{L} / \operatorname{trn} \mathrm{F}$ sequence data. Systematic Botany 28, 558-566.

Moore G (2007) The handling of the proposal to conserve the name Acacia at the 17 th international botanical congress - an attempt at minority rule. Bothalia 37, 109-118.

Moore G (2008) Action on the proposal to conserve the name Acacia at the nomenclature section of the XVII international botanical congress in Vienna: did the ayes have it? The Linnean 24, 16-20.

Moore A, Cotterill FPD (2011) The Acacia retypification debate: perspectives of African amateur botanists. Taxon 60, 858-859.

Moore G, Smith GF, Figueiredo E, Demissew S, Lewis G, Schrire B, Rico L, van Wyk AE (2011a) Acacia, the 2011 nomenclature section in Melbourne, and beyond. Taxon 59, 1188-1195.

Moore G, Smith GF, Figueiredo E, Demissew S, Lewis G, Schrire B, Rico L, van Wyk AE, Luckow M, Kiesling R, Sousa SM (2011b) The Acacia controversy resulting from minority rule at the Vienna nomenclature section: much more than arcane arguments and complex technicalities. Taxon 3, 852-857.
Olmstead RG, Sweere JA (1994) Combining data in phylogenetic systematics: an empirical approach using three molecular data sets in the Solanaceae. Systematic Biology 43, 467-481. doi:10.1093/sysbio/43.4.467

Orchard AE, Maslin BR (2003) (1584) Proposal to conserve the name Acacia (Leguminosae: Mimosoideae) with a conserved type. Taxon 52, 362-363. doi: $10.2307 / 3647418$

Pedley L (1987) In defence of Racosperma. Bulletin of the International Group for the Study of Mimosoideae 15, 123-129.

Pedley L (1989) Racosperma again. Australian Systematic Botany Newsletter 59, 1-2.

Rico Arce L, Bachman S (2006) A taxonomic revision of Acaciella (Leguminosae, Mimosoideae). Anales del Jardin Botanico de Madrid 63, 189-244.

Robinson J, Harris SA (2000) A plastid DNA phylogeny of the genus Acacia Miller (Acacieae, Leguminosae). Botanical Journal of the Linnean Society 132, 195-222. doi:10.1111/j.1095-8339.2000.tb01527.x

Ronquist F, Huelsenbeck JP (2003) MRBAYES 3: Bayesian phylogenetic inference under mixed models. Bioinformatics 19, 1572-1574. doi:10.1093/bioinformatics/btg180

Seigler DS, Ebinger JE (2005) New combinations in the genus Vachellia (Fabaceae: Mimosoideae) from the New World. Phytologia 87, 139-178.

Seigler DS, Ebinger JE (2009) New combinations in the genus Senegalia (Fabaceae: Mimosoideae). Phytologia 91, 25-29.

Seigler DS, Ebinger JE (2010) New combinations in Senegalia and Vachellia (Fabaceae: Mimosoideae). Phytologia 92, 90-93.

Seigler DS, Ebinger JE, Miller JT (2006a) Mariosousa, a new segregate genus from Acacia s.l. (Fabaceae, Mimosoideae) from Central and North America. Novon 16, 413-420. doi:10.3417/1055-3177(2006)16[413:MANSGF]2.0.CO;2

Seigler DS, Ebinger JE, Miller JT (2006b) The genus Senegalia (Fabaceae: Mimosoideae) from the New World. Phytologia 88, 38-93.

Smith GF, Figueiredo E (2011) Conserving Acacia Mill. with a conserved type: what happened in Melbourne? Taxon 60, 1504-1506.

Smith GF, van Wyk AE, Luckow M, Schrire B (2006) Conserving Acacia Mill. with a conserved type. What happened in Vienna? Taxon 55, 223-225. doi:10.2307/25065547

Smith GF, Figueiredo E, Moore G (2010) Who amends the international code of botanical nomenclature? A response to Applequist et al. (2010). Taxon 60, 213-215.

Spegazzini CL (1921) Acacieas Argentinas. Boletin de la Academia Nacional de Ciencias 26, 161-334.

Swofford DL (2003) 'PAUP*. Phylogenetic analysis using parsimony $(*$ and other methods). Version 4.' (Sinauer Associates: Sunderland, MA)

Thiele KR, Funk VA, Iwatsuki K, Morat P, Peng C-I, Raven PH, Sarukh NJ, Seberg O (2011) The controversy over the retypification of Acacia Mill. with an Australian type: a pragmatic view. Taxon 60, 194-198.

van Rijckevorsel VP (2006) Acacia: what did happen at Vienna? Anales del Jardin Botanico de Madrid 61, 107-110.

Vassal J (1972) Apport des recherches ontogeniques et seminologiques a l'etude morphologique, taxonomique et phylogenique de genre Acacia. Bulletin de la Societe d' Histoire de Toulouse 108, 125-247.

Willdenow CL (1806) 'Caroli a Linne Species Plantarium', 4th edn, vol. 4. (Imprentis G. C. Nauk: Berlin) 
Appendix 1. Taxa, voucher specimens and Genbank numbers of taxa sampled in the present study All Seigler collections are lodged at ILL. All collections new to the present study are italicised

Acacia ampliceps Maslin, CANB 615617, EU439993, EU811844, EU811961

Acacia aneura F.Muell. ex Benth., CANB 615661, EU440012, EU811865 EU812036

Acacia tumida F.Muell. ex Benth., CANB 615614, AF195692 AF195673, EU811863, AF195724, AF523100

Acaciella angustissima (Mill.) Britton \& Rose var. angustissima, D. Seigler 15993, EU440019, EU811872, EU811979, EU812043

Acaciella tequilana Britton \& Rose, AR1206, EU440020, EU811873, EU811980, EU812044, EU811919

Acaciella villosa (Sw.) Britton \& Rose, DLEG 96-02580, EU440018, EU811871, EU812042

Albizia harveyi Fourn., DLEG 91-0136, EU439977, EU811828, EU811945, EU812003, EU811900

Albizia julibrissin Durazz., DLEG 92-0266, EU439984, EU811835, EU811952, EU812010, EU811907

Albizia kalkora Prain, CANB 615621, EU440040, EU811895, EU811999, EU812063, EU811940

Albizia procera Benth., D. Seigler 14502, EU440009, EU811861, EU811975, EU812033

Albizia spp., DLEG 92-0265, EU439975, EU811826, EU811943, EU812001, EU811898

Anadenanthera colubrina (Vell.) Brenan, L. Coradin, 5915 Kew, EU440037, EU811892, EU811996, EU812060, EU811937

Anadenanthera peregrina Speg., D. Seigler 14543, EU440022, EU811875, EU811982, EU812046, EU811921

Calliandra juzepczukii Stand1., CANB 615620, EU440039, EU811894, EU811998, EU812062, EU811939

Calliandra longipedicella (McVaugh) Macqueen \& H. M.Hern., CANB 615621, EU439978, EU811829, EU811946, EU812004, EU811901

Calliandra sp., D.Seigler 14513, EU440004, EU811856, EU812028, EU811971

Chloroleucon guantanamense (Britton) Britton \& Rose, D. Seigler 14537, EU439989, EU811840, EU811957, EU812015, EU811912

Chloroleucon mangense Britton \& Rose, CANB 615623, EU439982, EU811832, EU811949, EU812007, EU811904

Cojoba filipis (Vent.) Barneby \& J.W.Grimes, D. Seigler 14541, EU440007, EU811859, EU811973, EU812031

Desmanthus virgatus (L.) Willd., D. Seigler 14494, EU440011, EU811864, EU811976, EU812035

Ebenopsis ebano (Berland.) Barneby \& J.W.Grimes, D. Seigler 15957, EU439986, EU811837, EU811954, EU812012, EU811909

Faidherbia albida (Delile) A.Chev., CANB 615551, AF522943, EU811854, AF524963, AF274120

Faidherbia albida (Delile) A.Chev., CANB 632235, EU440024, EU811877 AF523189, EU811923

Leucaena leucocephala (Lam.) de Wit, D. Seigler 15944, EU439990, EU811841, EU811958, EU812016, EU811913

Lysiloma tergeminum Benth., CANB 615625, EU439981, EU811833, EU811950, EU812008, EU811905

Mariosousa coulteri (Benth.) Seigler \& Ebinger, D. Seigler 15953, EU440034, EU811889, EU811993, EU812057, EU811934

Mariosousa dolichostachya (S.F.Blake) Seigler \& Ebinger, D. Seigler 16040, EU440033, EU811888, EU811992, EU812056, EU811933

Mariosousa millefolia (S.Watson) Seigler \& Ebinger, DLEG, EU440035, EU811890, EU811994, EU812058, EU811935

Mimosa casta L., D. Seigler 14545, EU439999, EU811850, EU811967, EU812023

Mimosa foetida Jacq., CANB 615630, EU439994, EU811845, EU811962 EU811916

Neptunia monosperma F.Muell. ex Benth., CANB 9102794, EU439979, EU811830, EU811947, EU812005, EU811902

Pararchidendron pruinosum (Benth.) I.C.Nielsen, ANBG 8200992, EU439985, EU811836, EU811953, EU812011, EU811908

Paraserthianthes lophantha (Willd.) I.C.Nielsen, ANBG 7901474, EU440016, EU811869 EU812040

Piptadenia viridiflora Benth., C. Hughes 1681 OFI, EU439980, EU811831, EU811948, EU812006, EU811903

Pithecellobium unguis-cati Benth., D. Seigler, 14477, EU439988, EU811839

Prosopis juliflora (Sw.) DC, D. Seigler 14481, EU439987, EU811838, EU811955, EU812013, EU811910

Senegalia brevispica (Harms) Seigler \& Ebinger, T. Young 3151, Mpala, EU440013, EU811866, EU811977, EU812037, EU811918

Senegalia galpinii (Burtt Davy) Seigler \& Ebinger, C. W. Fagg 574 FHO, EU440000, EU811851, EU811968, EU812024

Senegalia gaumeri Britton \& Rose, D. Seigler 16030, EU440038, EU811893, EU811997, EU812061, EU811938

Senegalia gilliesii (Steud.) Seigler \& Ebinger, DLEG94-0167, EU439992, EU811843, EU811960, EU812018, EU811915

Senegalia mellifera (Vahl) (Seigler \& Ebinger), T. Young 3168, Mpala, EU440029, EU811883, EU811988, EU812052, EU811929

Senegalia muricata (L.) Britton \& Rose, D. Seigler 14548, EU440008, EU811860, EU811974, EU812032, EU440008

Senegalia occidentalis (Rose) Britton \& Rose, D. Seigler 16158, EU440032, EU811886, EU811991, EU812055, EU811931

Senegalia picachensis (Brandegee) Britton \& Rose, D. Seigler 15981, EU439983, EU811834, EU811951, EU812009, EU811906

Senegalia skleroxyla (Tussac) Seigler \&Ebinger, D. Seigler 14503, EU440006, EU811858, EU811972, EU812030

Senegalia sororia (Stand1.) Britton \& Rose, D. Seigler 16067, EU439991, EU811842, EU811959, EU812017, EU811914

Senegalia visco (Lorentz ex Griseb.) Seigler \& Ebinger, CANB 615607, EU440036, EU811891, EU811995, EU812059, EU811936

Senegalia vogeliana (Steud.) Britton \& Rose, D. Seigler 14501, EU440001, EU811852, EU811969, EU812025

Vachellia choriophylla (Bentham) Seigler \& Ebinger, UI Ghse s.n., EU440017, EU811870 EU812041

Vachellia collinsii (Safford) Seigler \& Ebinger, D. Seigler 16038, EU440031, EU811885, EU811990, EU812054, EU811930

Vachellia constricta (Bentham) Seigler \& Ebinger, D. Seigler 16061, EU440028, EU811881, EU811987, EU812051, EU811927

Vachellia cornigera (L.) Seigler \& Ebinger, D. Seigler 16049, EU440021, EU811874, EU811981, EU812045, EU811920

Vachellia cucuyo (Barneby \& Zanoni) Seigler \& Ebinger, D. Seigler 14534, EU440010, EU811862 EU812034

Vachellia grandicornuta (Gerstner) Seigler \& Ebinger, CANB 632220, EU440026, EU811879, EU811985, EU812049, EU81192

Vachellia hockii (De Wild.) Seigler \& Ebinger, T. Young 3199 Mpala, EU440014, EU811867, EU811978, EU812038

Vachellia macracantha (Humboldt \& Bonpland ex Willdenow) Seigler \& Ebinger, D. Seigler 16052, EU440030, EU811884, EU811989, EU812053

Vachellia nilotica (L.) P.J.Hurter \& Mabb., CANB 615592, AF522979, EU811827, AF524999, AF523183, EU811899

Vachellia oviedoensis (R.García \& M.Mejía) Seigler \& Ebinger, D. Seigler 14529, EU440005, EU811857 EU812029

Vachellia schaffneri (S.Watson) Seigler \& Ebinger, D. Seigler 15931

Vachellia vernicosa (Britton \& Rose) Seigler \& Ebinger, D. Seigler 16062, EU440025, EU811878, EU811984, EU812048, EU811924

Zapoteca nervosa (Urb.) H.M.Hern., D. Seigler 14535, EU439997, EU811848, EU811965, EU812021 